\title{
ВІЙНА ЯК ЧИННИК ФУНКЦІОНУВАННЯ ТА ЗМІНИ ПОЛІТИЧНИХ СИСТЕМ
}

\begin{abstract}
Анотація. Встановлено, що провідним фактором, який вплинув на появу перших політичних систем, була війна. Удосконалення технологій і знарядь полювання, підвищення їхньої ефективності призвело до росту чисельності населення та винищення біомаси у місцях розселення. Зазначене зіштовхнуло інтереси сусідніх племен, стимулювало появу війн за територію та виступило одним iз факторів створення перших держав. Досліджено місце та роль війни у становленні та функціонуванні ранніх держав. Логіка функціонування політичних систем країн стародавнього Сходу зводилась до завоювання та експлуатації нових територій. Вказані політичні утворення характеризуються як держави-імперії, в яких провідну роль відігравала війна. 3'ясовано, що через природно-кліматичні умови держави античного світу мали суттєві відмінності, однак війна залишалась невіддільним елементом функціонування їх політичних систем.
\end{abstract}

Встановлено, що в період Європейського середньовіччя загальна конструкція та місце війни у політичних системах Східних держав не змінилось. Феодальні політичні системи мали певні особливості, однак це не виключало війни як ключового чинника їх функціонування. Виявлено, що в межах перебудови світової системи в Нові часи провідну роль почали грати колоніальні війни. Вони сприяли первинному накопиченню капіталу, завоюванню ресурсів та нових ринків збуту. Встановлено, що вказані процеси заклали основу для науково-технічного прогресу та вплинули на формування сучасної цивілізації. Протиріччя навколо колоніальної системи, а саме бажання «нових індустріальних держав» iіi перерозподілу, виступили провідним чинником розв'язання Першої та Другої світових війн.

3'ясовано, що особливості функціонування провідних країн у межах біполярного світу провокували локальні військові конфлікти та постійну загрозу глобальної війни. Логіка існування світової політичної системи цього періоду передбачала перманентний конфлікт між геополітичними центрами та підштовхувала США і СРСР втручатись у кожен військовий конфлікт, що виникав у будь-якій частині світу. Розпад вказаної системи міжнародних відносин оголив територіальні претензії багатьох країн, що намагались розв'язати їх за рахунок війни. Встановлено, що ключові перетворення світу кінця XX - початку XXI ст. не вилучили війну з механізму функціонування політичних систем. Новітні технології - високоточна зброя, засоби інформаційного забезпечення, космічні та повітряні системи розвідки, автоматизовані системи бойового управління, лише сприяють використанню війни у політичному процесі.

Ключові слова: війна, зовнішнє збройне насилля, політичні системи, політичний процес, світ-імперія, світ-економіка.
Постановка проблеми. Очевидним є той факт, що війна використовувалась протягом усієї історії людства як потужний засіб впливу на політичні системи. За допомогою цього виду збройного насилля з'являлись нові держави i зникали інші, змінювались правителі і політичні режими, розповсюджувались знання і нав'язувалась антигуманна ідеологія. Сучасний світ характеризується приголомшуючими досягненнями науково-технічного прогресу, інформатизацією та становленням глобальної економіки. Однак указані фактори не підштовхнули до відмови від війни як чинника впливу на політичний процес, змінились лише засоби іiі реалізації. Враховуючи викладене, а також те, що наша держава безпосередньо стикнулась із новітніми формами війни, вважаємо актуальним виявити місце та роль указаного явища у функціонуванні та зміні політичних систем.

Аналіз останніх досліджень і публікацій. Проблемам, пов'язаним із війною, приділяли увагу ще мислителі стародавніх часів, зокрема, античні філософи Геракліт, Демокрит, Платон та Аристотель, давньокитайський теоретик та полководець Сунь-цзи. У період Відродження та Просвітництва війну під різними кутами зору аналізували Н. Макіавеллі, Дж. Локк, I. Кант та інші. Класиком світової військової науки вважається прусський воєнний теоретик К. фон Клаузевіц. Значу увагу вказаним проблемам приділяв французький соціолог Р. Арон та англійський історик, соціолог та геополітик А. Тойнбі. Серед сучасних вітчизняних науковців, роботи яких пов'язані з темою нашої розвідки, можна назвати: О. Феденко та В. Панасюка [1], Н. Макаренко [2], В. Лавриненко та М. Логінова [3], Ю. Бадаха [4]. Однак зазначені дослідники приділяли увагу теоретичному осмисленню категорій «війна», а її̈ вплив на політичний процес залишився поза увагою.

Метою статті $є$ виявлення впливу війни на появу перших політичних систем; дослідження місця вказаного феномену у функціонуванні політичних систем минулого та сучасності; надання характеристики провідним причинам застосування війни як засобу внутрішньої та зовнішньої політики; аналіз наслідків змін у технології застосування вказаного виду збройного насилля наприкінці XX - на початку XXI ст.

Виклад основного матеріалу дослідження. Війна як суспільне явище з'явилась раніше появи перших держав та, відповідно, політичних систем. Однак цілком очевидно, що саме війна виступила одним із провідних чинників становлення зазначених інституцій. Зокрема, завершення льодовикового періоду, що призвело до заміни крупних тварин малими та прудкими, стимулювало удосконалення технологій та знарядь полювання, суттєве підвищення його ефективності. 
Вказані процеси призвели, з одного боку, до росту чисельності населення, з іншого - до винищення біомаси у місцях розселення. Все це своєю чергою зіштовхнуло інтереси сусідніх племен та стимулювало появу перших війн за територію. На наш погляд, зазначена конфронтація виступила одним із факторів, що підштовхнув перехід до виробничого типу господарства та створення перших держав.

Як відомо, перші держави з'явились на Сході, стимулом до ïx появи була необхідність будівництва та підтримки іригаційних систем для поливного землеробства. Об'єднати розрізнені племена та племенні союзи, організувати значну масу людей на громадські роботи можна було лише силою та жорстокою централізацією державного апарату. Політичні системи перших держав цілком відповідають світ-системному підходу I. Валерстайна. Це були держави-імперії, в яких провідну роль відігравала війна. Загалом основною сутністю таких державних утворень було завоювання та експлуатація нових територій. Зазначену тезу підтверджує протистояння між Вавилоном та Ассирією, історія функціонування Єгипту та Китаю тощо.

Західна цивілізація зародилась набагато пізніше та у інших природно-кліматичних умовах, що призвело до появи принципово інших та навіть аномальних для тодішньої світ-імпеpiї політичних систем. Однак це не означає, що війна не мала суттєвого впливу на існування античних держав. Так, навіть у Аттиці, як найбільш демократичному полісі Давньої Греції, усі громадяни чоловічої статі були воїнами. За реформами Салонна майнові розряди, що визначали об'єм політичних прав, були прив' язані до військового рангу. Доречно буде назвати і конструкцію політичної системи Стародавньої Лаконії, що загалом можна вважати державою - військовим гарнізоном. Зазначене виявлялось і у світосприйнятті давніх греків, які найголовнішою справою чоловіків вважали війну [5, с. 224].

Особливості та відмінності політичних систем стародавніх держав Західного світу поступово навіювались. Зокрема, імперію Олександра Македонського вже можна назвати типовим державним об'єднанням тодішньої світ-системи, з характерною логікою завоювання та експлуатації нових територій [6, с. 56]. Те саме ми бачимо в історії Стародавнього Риму, який протягом республіканського періоду еволюціонував у військову державу, згодом перетворився на імперію, заклав та розповсюдив політичні, державницькі та культурні основи Західного світу [2, с. 155].

У період Європейського середньовіччя політичні системи держав Сходу не змінюються. Могутні, стародавні імперії Єгипет, Вавилон, Ассирія зникають, однак їх місце займають арабські держави з такою ж політично конструкцією, характерною для світ-імперії. Ситуація на Заході була складнішою, тут відбувається становлення ранньофеодальних монархій, політичні системи яких суттєво відрізнялись як від Східних держав, так і від Риму. Розпочали цей процес завоювання давньогерманських племен, що призвело до остаточного зникнення Римської імперії та стимулювало необхідність створення нової державності.

Війна у функціонуванні політичних систем феодальних держав також відігравала значну роль. Політична еліта зазначених країн складалась саме з військової верхівки. Підкреслимо, що подібна політична організація стимулювала постійні міжусобні війни. Реформи Карла Мартелла у ранньофеодальній державі Франків сформували чітку взаємозалежність між воло- дінням землею, а, відповідно, політичним пануванням та військовою службою феодала на короля. У політичних системах феодального типу існувала ще одна особливість, що стимулювала міжусобні війни, а саме: принцип престолонаслідування. Вказаний чинник призвів до розпаду Франкської імперії, заклав основу самостійного існування більшості європейських країн та постійних війн між ними. Враховуючи переплетеність урядових та церковних структур середньовічних держав, релігійні війни як у середині Європейського континенту, так і хрестові походи слід вважати елементом функціонування тодішніх політичних систем [7, с. 30].

Слабкість імперії Габсбургів зумовила іiі неспроможність побудувати державні структури, характерні для тодішньої світ-системи. Відсутність ефективного, силового механізму панування над Європейськими народами призвела до корінних політичних змін у державах указаного регіону та стимулювала становлення кардинально іншої світ-економіки. Логіка функціонування політичних систем у нових умовах суттєво змінюється, основою тепер виступає не завоювання та експлуатація, а механізми, характерні для ринкових відносин. Проте війна як чинник політичного процесу не зникає та отримує нові форми. До нового типу зовнішнього збройного насилля, що стимулюється механізмами світ-економіки, а саме первинним накопиченням капіталу, завоюванням ресурсів та ринків збуту, слід віднести колоніальні війни.

Колоніальні завоювання призвели до розповсюдження нових товарів у Європі, революції цін та безконфліктного становлення абсолютних монархій. У межах зазначеної форми правління було закладено основи нового економічного устрою, нові ідеали світосприйняття, що у кінцевому рахунку лягло в основу подальших революційних рухів. Завершився процес становлення нової системи у Європі також через війни, а саме Наполеонівські. На зазначений економічний складник війн Нового періоду звертає увагу і відомий французький історик М. Блок, який, характеризуючи юридичні та моральні мотиви війни, наголошував на економічному аспекті війни як джерелі прибутку певних держав [8, с. 306].

Особливості функціонування провідних держав у системі світ-економіка стимулювали не лише колоніальні війни. Наприкінці XIX - на початку XX ст. вказані фактори призвели до бажання «нових індустріальних держав» перерозподілити світову колоніальну систему, що стало основною причиною Першої, а згодом і Другої світових війн. Міжвоєнний період також характеризується політичною нестабільністю та нарощенням військової потужності держав, що, на думку С. Хантингтона, зводилось до чотирьох аспектів: кількісного (жива сила, зброя та ресурси); технічного (ефективність озброєння); організаційного (розгортання і бойовий дух військ); та соціоетального (здатність і готовність залучити збройні сили в різних ситуаціях) [3, с. 165-164].

На наш погляд, слід додати, що у міжвоєнний період реваншизм, поєднаний з бажанням перерозподілу світових ресурсів, призвів до появи та розповсюдження тоталітарних режимів у деяких європейських країнах. В основі існування подібних політичних систем було закладено відкрите агресивне ставлення до сусідніх країн та намагання вирішити власні проблеми за допомогою війни. Цікавим є той факт, що напередодні Другої світової війни провідні економісти вже наголошували на безперспективності намагань прискорити економічне зростання 
держави за рахунок війни, та на тому, що покращення добробуту залежить від розширення міжнародного поділу праці $[9$, c. 780$]$.

Світові війни у підсумку трансформували деякі риси сучасної світ-системи. Зокрема, представники Кембриджського університету виокремили три основні зміни. По-перше, економічне зростання та, відповідно, логіка функціонування політичних систем західноєвропейських держав перестали залежати від наявності колоній. По-друге, у вказаних країнах зростає тенденція до співробітництва, як між собою, так і з США, що заклало основу європейської інтеграції та співробітництва 3 країнами, що розвиваються в процесі деколонізації. По-третє, централізація влади в межах війни навчила європейських лідерів використовувати державні механізми для регулювання ринкових відносин та запобігання кризи перевиробництва [10, с. 219-220].

Однак зазначені зміни не ліквідували інститут війни у світовій політичній системі. Навпаки, логіка існування біполярного світу передбачала перманентний конфлікт між геополітичними центрами та підштовхувала США і СРСР втручатись у кожен військовий конфлікт, що виникав у будь-якій частині світу $[4$, с. 90]. Зокрема, вказаний чинник призвів до масштабності, гостроти та безкомпромісності війн між державно сформованими частинами однієї нації, що були поділені за політико-ідеологічними, регіональними і соціально-економічними принципами. Сюди слід віднести війну у Кореї (1950-1953рр.), В’єтнамі (1964-1973рр.), Йемені (1963-1967рр.). Окрім того, війна як механізм політики застосовувалась світовими лідерами задля утримання в своїй орбіті країн, що намагалися змінити геополітичний вектор (Лаос, 1960-1970 рр., Конго, 1960-1968 рр., ГДР, 1948-1949, 1953, 1961 рр., Угорщина, 1956 р., Чехословаччина, 1968 р.).

Розпад біполярної системи міжнародних відносин оголив територіальні претензії багатьох країн, особливо новостворених, що не бажали визнавати колишні адміністративні кордони та намагались розв'язати свої проблеми за рахунок війни (Іран, Ірак, Індія, колишні Югославія та СРСР, Перу, Еквадор тощо) $[4$, c. 93]. Окрім того, друга половина ХХ ст. позначилась суттєвим удосконаленням технологій ведення війни, що надавало провідним державам додаткові можливості її застосування у зовнішньополітичній практиці. Так, у зоні Перської затоки в 1991 р. було використано понад 100 нових видів зброї. Загалом операцію «Буря в пустелі» слід уважати корінним переломом у військовій справі, під час якої класична війна перетворилась на високотехнологічну [1, с. 220].

Сучасні дослідники по-різному оцінюють процеси, що сьогодні відбуваються в Світі. Частина вважає, що глобалізація та інформатизація - це передвісники корінних змін, а людство знаходиться на порозі нової ери, становлення нової світ-системи. Інші скептично ставляться до подібних висловлювань, уважаючи, що вказані процеси не ведуть до сутнісних трансформацій. Так чи інакше, війна залишається елементом функціонування політичних систем, а новітні технології - високоточна зброя, засоби інформаційного забезпечення, космічні та повітряні системи розвідки, автоматизовані системи бойового управління, цьому лише сприяють [11, с. 72-73]. Незмінними залишаються і політичні цілі війни [12, с. 7].

Висновки. Таким чином, війна є одним із провідних факторів, що вплинули на появу перших політичних систем. Вона стає невіддільним елементом політичного процесу в період становлення ранніх держав та поступово формує світ-імперію, основною логікою якої є завоювання та експлуатація. Західний світ мав певні політичні особливості як у античний, так і в середньовічний період. Однак війна не виключалась з основних чинників функціонування політичних систем цього регіону. Становлення нової світ-економіки докорінно змінило логіку розвитку провідних держав. Невіддільним елементом політичного процесу стають колоніальні війни, а протистояння європейських країн за колонії призвело до розв'язання двох світових війн. Основною причиною збройних конфліктів другої половини XX ст. слід вважати протиборство політичних систем двох центрів біполярного світу. Розпад соціалістичного табору, процеси глобалізації та інформатизації, використання новітніх засобів ведення війни розкривають нові горизонти подальшого вивчення заявленої проблеми.

\section{Jimepamypa:}

1. Феденко О.В., Панасюк В.В. Еволюція змісту сучасної війни. Військово-науковий вісник. 2015. Вип. 24. С. 219-230.

2. Макаренко Н.Г. Філософсько-концептуальний вимір категорії «війна» в історії філософсько-політичної думки. Філософські обрії: Науково-теоретичний часопис. 2004. № 12. С. 152-164.

3. Лавриненко В.М., Логінов М.М. Війна як суспільний феномен (філософсько-економічні виміри). Парадигмальні зрушення в економічній теорії XXI cm. : матеріали II Міжнар. наук.-практ. конф. (15-16 жовт. 2015 р.) / М-во освіти і науки України, Київ. нац. ун-т ім. Т. Шевченка ; редкол.: В.Д. Базилевич (голов. ред.) [та ін.]. Київ : КНУ ім. Тараса Шевченка, 2015. С. 163-167.

4. Бадах Ю. Причини виникнення та класифікація воєнних конфліктів. Воєнна історія. 2003. № 3-4. С. 83-89.

5. Тері Ірен. Адамово ребро. Повернення до демократичного парадоксу Esprit. № 273. marsavril. 2001. (Реферативний огляд SENTENTIAE: наукові праці спілки дослідників модерної філософії (Паскалівського товариства). IV. № 2. 2001. С. 78-90.

6. Снесарев А. Философия войны. Глава III. Война в исторической перспективе. Военно-исторический журнал. № 3. 2002. С. 112-118.

7. Арон Р. Мир і війна між націями ; пер. 3 фр. : В.І. Шовкун ; пер. 3 фр. [та ін.] . Київ : Юніверс, 2000. 685 с.

8. Блок М. Феодальне суспільство: Пер. $з$ фр. Київ : Вид. Дім «Всесвіт». 2001. $528 \mathrm{c}$.

9. Мизес Л. Человеческая деятельность: Трактат по экономической теории. Москва : Экономика. 2000. 878 с.

10. Кембриджская экономическая история Европы Нового и Новейшего времени. Т. 2. Москва : Изд-во Института Гайдара, $2013.624 \mathrm{c}$

11. Капитанец И. М. Битва за мировой океан в «холодной» и будущих войнах. Москва : Вече, 2002. 544 с.

12. Капитанец И.М. Флот в войнах шестого поколения. Москва : Вече, $2003.480 \mathrm{c}$

Bader A. War as a factor of functioning and change of political systems

Summary. It was found that war was the leading factor influencing the emergence of the first political systems. Improvement of technologies and tools of hunting, increase of its efficiency has led to increase of population and biomass destruction in settlements. This pushed the interests of the neighboring tribes, stimulated the emergence of wars for the territory and was one of the factors of creation of the first states. The place and role of war in the formation and functioning of the early states are investigated. The logic of the functioning of the political systems of the countries of the ancient East was to conquer and exploit 
new territories. These political entities are characterized as empire states in which war played a leading role. It was found that the natural and climatic conditions of the ancient world had significant differences, but war remained an integral part of the functioning of their political systems.

It is established that during the European Middle Ages the general construction and place of war in the political systems of the Eastern states didn't change. Feudal political systems had certain characteristics, but this didn't rule out war as a key factor in their functioning. It is revealed that colonial wars began to play a leading role in the restructuring of the world system in modern times. They contributed to the initial accumulation of capital, the conquest of resources and new markets. It is established that these processes formed the basis for scientific and technological progress and influenced the formation of modern civilization. The controversy surrounding the colonial system, namely the desire of the "new industrial powers" of its redistribution, was a leading factor in the outbreak of the First and Second World Wars.
It is revealed that the peculiarities of the functioning of the leading countries within the bipolar world have provoked local military conflicts and the constant threat of global war. The logic of the existence of a world political system during this period implied a permanent conflict between geopolitical centers and prompted the US and the USSR to intervene in every military conflict that arose in any part of the world. The collapse such system of international relations exposed the territorial claims of many countries that sought to resolve them at the expense of the war. It is established that the key transformations of the world of the late XX - early XXI centuries didn't remove the war from the mechanism of political systems functioning. The latest technologies high-precision weapons, information support, space and air reconnaissance systems, automated combat systems - only contribute to the use of war in the political process.

Key words: war, external armed violence, political systems, political process, world-empire, world-economy. 